\title{
Implementation of Traditional Medicine Remedies During The COVID-19 Pandemic as Health Improvement and Empowerment of Indonesian Women
}

\author{
Dhigna Luthfiyani Citra Pradana ${ }^{1 *}$, Eldiza Puji Rahmi ${ }^{2}$, \\ Annisa Farida $\mathrm{Muti}^{3}$ \\ ${ }^{123}$ Pharmacy Department of Medical Faculty, Universitas Pembangunan “Veteran” Jakarta \\ Author E-mail: dhignaluthfiyani@upnvj.ac.id
}

\begin{abstract}
A B S T R A C T
The COVID-19 pandemic is still a polemic of life in the world. WHO explains that there are still several countries showing an increase in COVID-19 incident. There are still active cases of COVID-19 in Indonesia, which is why Indonesian people should remain vigilant and follow the instruction of the Indonesian Ministry of Health, and do the 5M. In addition, the Ministry of Health in Indonesia also recommends using traditional medicine to maintain health, provide adequate nutrition and help overcome health problems. Muslim women groups from various regions in Indonesia can be suitable subjects of community service to assist the government in overcoming the COVID-19 pandemic, one of which is through education about COVID-19 and traditional medicine used during the COVID-19 pandemic. The method used in this community service is through educational webinars and measurement of understanding using an electronic questionnaire. After the educational webinar, the team collected the participant's activity in implementing traditional medicine during the COVID-19 pandemic. The results of this community service activity increased the knowledge of the community service participants to 85.83\%. The participants also implemented traditional medicine by sending photos of the activities of the community service participants. This community service activity aims to overcome the problem of information gaps and increase the knowledge of Muslim women groups from various regions in Indonesia to improve and maintain the quality of life and health during the COVID-19 pandemic. Participants in this activity look active and enthusiastic during community service activities.
\end{abstract}

Keywords: COVID-19, Herbal Medicine, Immunity. permits unrestricted use, distribution, and reproduction in any medium, provided the original work is properly cited.

\section{INTRODUCTION}

SARS-COV-2 is the virus that causes Corona Virus Disease 2019 (COVID-19). COVID-19 is a disease that has created an imbalance in social life and created abnormal conditions. Until now, the COVID-19 pandemic is still being felt by the entire world community, including Indonesia (Cucinotta \& Vanelli, 2020). Based on data from 
WHO, the number of COVID-19 cases globally is reported that now totals more than 220 million, and the total number of deaths is more than 4.5 million. In addition, several incidents in America were reported to have increased by the end of this week by $19 \%$ compared to last week. In contrast, in several regions in Africa, Asia and Europe, COVID-19 cases had decreased, including in Indonesia (Ministry of Health of Rwanda, 2021). Based on data from the COVID-19 Task Force in Indonesia, there has been a decline in active cases where people exposed to Sars-Cov-2 have decreased. The people of Indonesia must remain vigilant by taking care of themselves and their families with several appeals from the Indonesian government. The Indonesian government urges the Indonesian government to maintain health protocols and implement 5M (Using Masks, Washing Hands, Keeping Distance, Staying away from Crowds, Reducing Mobility) (Inherni Marti Abna, 2021). Indonesian people should maintain immunity when doing activities outside the home or interacting directly with COVID-19 patients. Circular Letter Number: HK.02.02/IV.2243/2020 from the Directorate General of Health Services, Ministry of Health of the Republic of Indonesia, explains the use of traditional medicines for health maintenance, disease prevention and health care, including during public health emergencies and the 2019 Coronavirus Disease National Disaster. (COVID-19) (Ministry of Health of Indonesia, 2020). The Government of Indonesia recommends using traditional medicinal herbs by the provisions and rules that are safe for the Indonesian people to maintain health and increase immunity during the COVID-19 pandemic. Therefore, the community service team organizes educational programs for groups of Muslim women from various regions in Indonesia. Representatives of Muslim women's groups from various regions in Indonesia are expected to obtain accurate information about COVID-19 and some of the prevention of the disease by using traditional Indonesian medicinal herbs. Starting from a group of women, the information will be shared to their family, neighbors and relatives regarding the safe use of traditional Indonesian medicinal herbs by the dosage to maintain health and increase immunity during the COVID-19 pandemic.

\section{METHODS}

Community service activities targeted all groups of Muslim women from various regions in Indonesia. In this community engagement example, Muslim women representing several regions in Indonesia participated in an educational webinar on COVID-19. The campaign is on traditional Indonesian medicinal ingredients and active compounds contained in traditional medicines that can be used during the COVID-19 pandemic. This community service activity uses a zoom meeting platform to make it easier for participants from various regions in Indonesia to participate in this activity. The number of participants who attended this community service activity was around 74 people from Riau, Sumatra, Central Java, East Java, West Java, Sulawesi, and Eastern Indonesia.

Before the Educational Activity started, the community service team asked the participants to work on a pre-test electronic questionnaire used to evaluate the participants' initial knowledge. The data is then analyzed by the community service team. Afterward educational activities were held with a webinar design attended by the community service team as event guides and resource persons. Educational background of the community service team from Pharmacy knows about the pathophysiology of COVID-19 disease, the mechanism of the immune response that occurs in COVID-19, prevention of COVID-19, the content of active compounds in traditional medicinal plants, and the traditional medicinal ingredients as recommended by the ministry of health. After the educational activity, the participants must complete the post-test electronic questionnaire that the community service team has provided. The community service team can use the pretest and post-test electronic questionnaire data to measure success in providing well-received education. Data processing were using Microsoft 
Excel and SPSS version 26 software. In addition, community service participants are also required to send photos of activities of making good traditional medicinal ingredients as requested by the community service team.

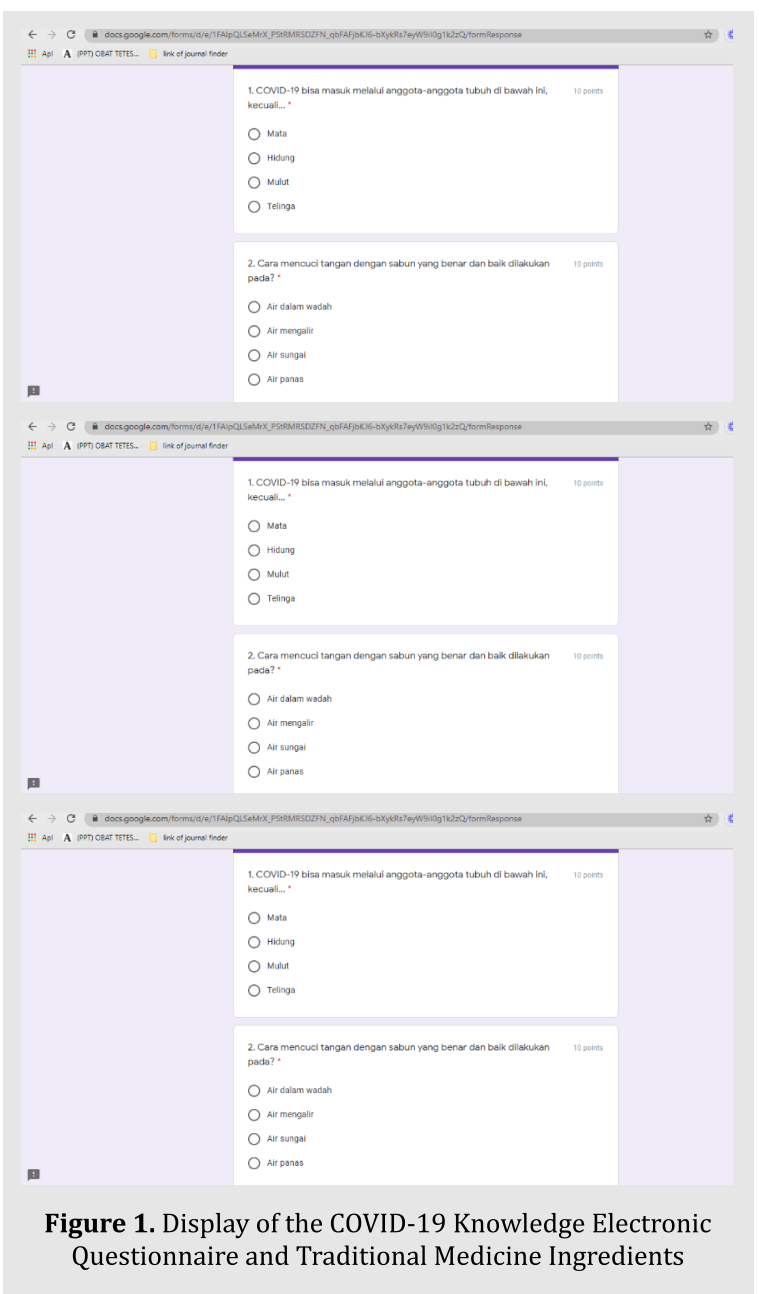

\section{RESULT AND DISCUSSION}

\section{Result}

Counselling activities are carried out online using zoom meetings. The counselling event went smoothly and was attended by 74 participants from NU (Nahdlatul Ulama) Muslim women throughout Indonesia. The following is a picture of traditional medicinal plant extension activities that can be used during the COVID-19 pandemic.

The counselling activity was attended by the Central NU Muslim Welfare Foundation chairman. He gave a speech and we thanked him for his excellent cooperation with this community service activity. The resource persons who provided counselling were divided into three topics regarding COVID-19 and the Ministry of Health's appeal in dealing with the COVID-19 pandemic delivered by Mrs. apt. Eldiza Puji Rahmi, M.Sc. The material about the active compounds contained in traditional medicinal plants was delivered by Mrs. apt. Dhigna Luthfiyani C.P., M.Sc, materials for traditional medicinal ingredients used during the COVID-19 pandemic were delivered by Mrs. apt. Annisa Farida Muti, M.Sc, and the Master of Ceremony were presented by Mrs Yosha Putri Wahyuni, SST., M. Biomed.

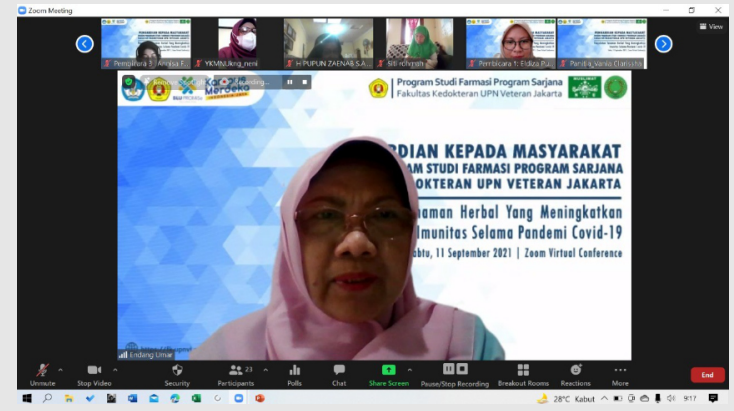

Figure 2. Chairperson of the Central NU Muslim Welfare Foundation

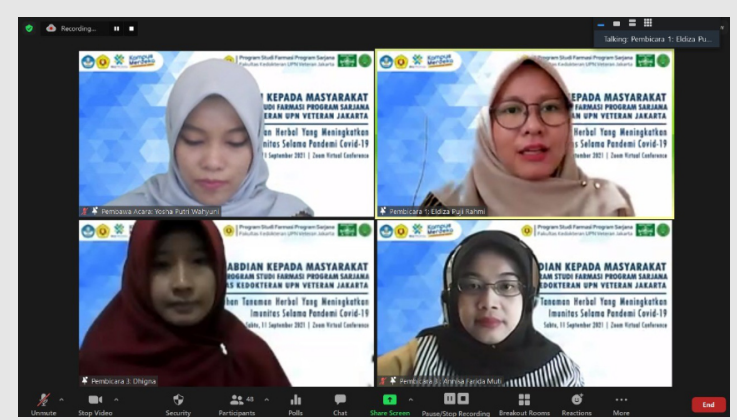

Figure 3. The Speakers \& Master of Ceremony of the online counselling activities

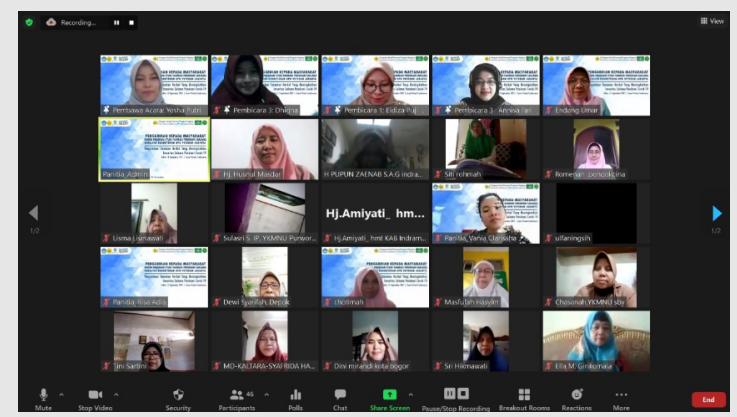

Figure 4. The Counselling Participants of Traditional Medicinal Plant 
The counselling participants were checked for their level of knowledge before they were given the education material and another post-test after being given the educational process. The topic of questions were about COVID-19 disease, the mechanism of the immune response that occurs in COVID-19, prevention of COVID-19, the content of active compounds in traditional medicinal plants, traditional medicinal ingredients according to the recommendations of the ministry of health as seen from the pretest and post-test scores.

According to the recommendations of the Ministry of Health (it can be seen from the pre-test and post-test scores): The average value of the pretest knowledge of Indonesian Muslim women about COVID-19 and Traditional Indonesian Medicine is 28.33. The average post-test score for the knowledge of Indonesian Muslim women about COVID-19 and Traditional Indonesian Medicine is 85.83 .

The results of the normality test using Kolmogorov Smirnov resulted in normally distributed data. In the paired t-test, the p-value of 0.00 means a difference between the pre-test and post-test scores for the level of knowledge of Indonesian Muslim women about COVID-19 and Traditional Indonesian Medicines where p-value $<0.05(95 \% \mathrm{CI})$. The mean value of the paired $t$ test results is -57.50 , negative means that there is a tendency to increase the knowledge level of community service participants after being given education with an average value of 57.50 .

\section{Discussion}

The community service participants have implemented the results of education about traditional medicinal ingredients, which can be seen from the photos of the activities of the community service participants sent via a google form electronic questionnaire to the community service team. Based on the assessment results of the level of knowledge of Indonesian Muslim women groups about COVID-19 and Traditional Indonesian Medicines, it shows an increase in the knowledge of community service participants. This activity can also explain that education programs regarding COVID-19, COVID-19 prevention, the content of active compounds in traditional medicinal plants, traditional medicinal ingredients according to the recommendations of the Ministry of Health have succeeded in increasing their level of knowledge. The community service team hopes that from this data, community service participants now have a good knowledge about COVID-19, and ways to prevent COVID-19 through active compounds contained in traditional Indonesian medicinal plants, and how to make excellent and safe Indonesian traditional medicinal ingredients. In addition, the level of quality of life and health of community service participants can also increase along with the increase in their knowledge.

The educational webinar activity about COVID-19, ways to prevent CovID-19, the active compounds contained in traditional Indonesian medicinal plants, and traditional Indonesian medicinal herbs went smoothly and wellmanaged. The community service participants looked enthusiastic by asking ten questions to the resource persons, and the speakers had answered them well.

This community service education is divided into three discussion topics. Topic 1 discusses COVID-19, the pathophysiology and mechanisms of COVID-19 immunity, prevention of COVID-19. Topic two discusses how to make traditional Indonesian medicinal herbs that can be used during the COVID-19 pandemic. Finally, topic 3 discuss the content of active compounds from traditional Indonesian medicinal plants. The three topics are made very comprehensive so that community service participants can understand the science of COVID-19 and traditional Indonesian medicinal herbs so that community service participants can implement them in daily life during the COVID-19 pandemic.

In the first topic regarding COVID-19, participants were asked to understand the brief 
pathophysiology and immune processes of COVID-19. Several studies show that increased biomarkers concentrations are associated with monocyte / macrophage, inflammasome, NF-B, neutrophil activation, activation and polarization of $\mathrm{T}$ cells, type I IFN and geneinduced response to IFN, endothelial damage in COVID-19 patients (Abers et al., 2021). These biomarkers trigger inflammation in COVID-19 patients. Traditional medicines containing active substances such as curcumin have pharmacological effects as an anti-inflammatory and increase immunity, which can help overcome this (Edwards et al., 2017). Some traditional Indonesian medicines that contain curcumin include turmeric and temulawak ((Hadi et al., 2018); (BPOM RI, 2020)).

The second and third topics of this community service activity are in the form of an educational webinar of making traditional Indonesian medicinal herbs that can be used during the COVID-19 pandemic and the active compounds in these traditional medicinal plants. The legal efficacy claims of traditional medicine are as traditional health use, for traditional treatment, and scientifically established treatment claims. Regarding traditional medicines used during the COVID-19 pandemic, they claim benefits as providing the function of nutrients, providing benefits to body functions and providing benefits in reducing disease risk (BPOM RI, 2020).

Other educators have also carried out education on traditional medicinal herbs under the name of socialization, counselling, planting, and utilization of family medicinal plants (TOGA). The activity was carried out using the TOGA type of counselling method, and its properties are easy to find and use around the residence of the extension participants. Apart from this, the educator also provides technical instructions on how to cultivate and plant TOGA. The result of this activity was that participants' knowledge about TOGA increased (Rahmawati et al., 2019). Furthermore, counselling on herbal medicinal plants during the COVID-19 pandemic has also been carried out under the title Cultivation of family medicinal plants and counselling of family medicinal plants for the prevention of COVID-19 in the village of Ngentak Pelem, Bangutapan, Bantul. The educators used training methods for cultivating medicinal plants, counselling on the benefits of medicinal plants, and training in making tea bags. As a result, participants planted TOGA in their yards and used these medicinal plants to prevent COVID-19 (Kusbandari, Aprilia ., Prasasti, P., Aryani, 2020).

The use of traditional medicinal herbs that need to be considered is how to cook these ingredients and use cooking utensils made of clay, heat-resistant glass, ceramics, porcelain, and stainless steel. The use of metals such as aluminum in traditional medicinal ingredients is not recommended because it can increase the risk of neurodegenerative diseases (Jabeen et al., 2016). Traditional medicinal ingredients must be washed thoroughly before further processing (Kementerian Kesehatan Republik Indonesia, 2018). In the use of dried Simplicia or dry traditional medicinal plants, attention should be focused on the presence of aflatoxin. Aflatoxin contamination of this fungal toxin can be a potential carcinogen and aflatoxin is produced from Aspergillus, where Aspergillus can only be damaged at a temperature of $269 \mathrm{oC}$ (Pereira et al., 2015).

\section{CONCLUSION AND RECOMMENDATION}

This community service activity is an effort to overcome the problem of information gaps and increase the knowledge of Muslim women groups from various regions in Indonesia so that the participants' quality of life and health can be improved and maintained during the COVID-19 pandemic. Participants in this activity looked active and enthusiastic during community service activities. The community service participants increased their knowledge about traditional medicinal herbs used during the COVID-19 pandemic, as seen in the increase in the knowledge post-test score of 85.83. The community service team advised the participants to apply the information and knowledge obtained about these traditional medicinal 
ingredients to their family, friends, neighbors, and the surrounding community. As a result, many Indonesians knew the benefits of traditional medicines that could be used during the COVID-19 pandemic.

\section{Acknowledgement}

We are much obliged to the Central NU Muslimat
Welfare Foundation Management, who have given permission and had cooperated well to implement this community service activity. Furthermore, we are much obliged to the Institute for Research and Community Service, Universitas Pembangunan Nasional Veterans Jakarta, for providing this community service grant.

\section{R E F E R E N C E}

Abers, M. S., Delmonte, O. M., Ricotta, E. E., Fintzi, J., Fink, D. L., Almeida de Jesus, A. A., Zarember, K. A., Alehashemi, S., Oikonomou, V., Desai, J. V., Canna, S. W., Shakoory, B., Dobbs, K., Imberti, L., Sottini, A., Quiros-Roldan, E., Castelli, F., Rossi, C., Brugnoni, D., ... Notarangelo, L. D. (2021). An immunebased biomarker signature is associated with mortality in COVID-19 patients. JCI Insight, 6(1), 1-20. https://doi.org/10.1172/jci.insight.144455

BPOM RI. (2020). Pedoman Penggunaan Herbal dan Suplemen Kesehatan dalam menghadapi COVID-19 di Indonesia (Cetakan Pe).

Cucinotta, D., \& Vanelli, M. (2020). WHO declares COVID-19 a pandemic. Acta Biomedica, 91(1), 157-160. https://doi.org/10.23750/abm.v91i1.9397

Edwards, R. L., Luis, P. B., Varuzza, P. V., Joseph, A. I., Presley, S. H., Chaturvedi, R., \& Schneider, C. (2017). The anti-inflammatory activity of curcumin is mediated by its oxidative metabolites. Journal of Biological Chemistry, 292(52), 21243-21252. https://doi.org/10.1074/jbc.RA117.000123

Hadi, S., Artanti, A. N., Rinanto, Y., \& Wahyuni, D. S. C. (2018). Curcuminoid content of Curcuma longa L. and Curcuma xanthorrhiza rhizome based on drying method with NMR and HPLC-UVD. IOP Conference Series: Materials Science and Engineering, 349(1). https://doi.org/10.1088/1757-899X/349/1/012058

Inherni Marti Abna. (2021). Edukasi Masyarakat Tentang Pentingnya Penerapan Protokol Kesehatan Dan Menjaga Imunitas Tubuh Dalam Rangka Pencegahan Corona Virus Disease (Covid-19) Di Desa Pesing Koneng Kedoya Utara Jakarta Barat. Jurnal Pengabdian Kepada Masyarakat, 01(9), 165-172.

Jabeen, S., Ali, B., Khan, M. A., Khan, M. B., \& Hasan, S. A. (2016). Aluminum Intoxication through Leaching in Food Preparation. Alexandria Science Exchange Journal: An International Quarterly Journal of Science Agricultural Environments, 37(October-December), 618-626. https://doi.org/10.21608/asejaiqjsae.2016.2539

KementerianKesehatanRepublikIndonesia. (2018). Surat Edaran tentang Pemanfaatan Obat Tradisional, Untuk Pemeliharaan Kesehatan, Pencegahan Penyakit dan Perawatan Kesehatan. Kementerian Kesehatan RI, 4247608(021), 613-614.

https://www.kemkes.go.id/article/view/19031800003/cegah-penyalahgunaan-narkobakemenkes-ajak-terapkan-germas.html\%0Ahttps://www.depkes.go.id/article/view/ 18030500005/waspadai-peningkatan-penyakit-menular.html\%0Ahttp://www.depkes.go.id/ article/view/1707070 
Kusbandari, Aprilia ., Prasasti, P., Aryani, C. (2020). Pembudidayaan tanaman obat keluarga dan penyuluhan tanaman obat keluarga untuk pencegahan Covid -19 di dusun Ngentak Pelem, Banguntapan, Bantul. Proceeding of Seminar Nasional Hasil Pengabdian Kepada Masyarakat, e-ISSN: 26(November), 873-878.

Ministry of Health of Rwanda. (2021). COVID-19 Weekly Epidemiological Update. World Health Organization, February, 1-33. https://www.who.int/publications/m/item/covid-19-weeklyepidemiological-update

Pereira, C. G., Silvia, J. R. O., \& Batista, L. R. (2015). Isolation and identification of toxigenic and nontoxigenic fungi in samples of medicinal plants from the market. Revista Brasileira de Plantas Medicinais, 17(2), 262-266. https://doi.org/10.1590/1983-084x/12_083

Rahmawati, A. I. E., Hardiyanto, D., Azhari, F., \& Suminar, A. (2019). Sosialisasi, penyuluhan, penanaman, dan pemanfaatan tanaman obat keluarga (TOGA). Jurnal Pemberdayaan: Publikasi Hasil Pengabdian Kepada Masyarakat, 3(3), 389-394. 